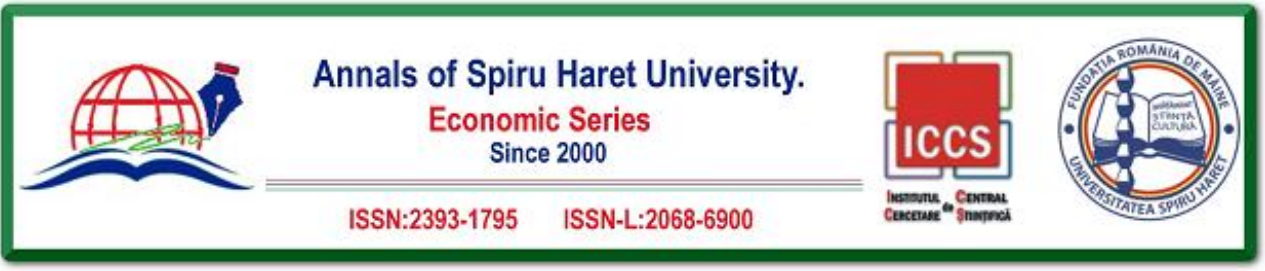

Issue 3/2018

\title{
THE IMPACT OF DEFLATION ON FISCAL AGGREGATES
}

\author{
Adina TRANDAFIR ${ }^{1}$, Octav NEGURIȚA ${ }^{2}$, Claudia GUNI ${ }^{3}$ \\ 1, 2, 3 Spiru Haret University, Faculty of Law and Economics, 32-34 Unirii \\ Street, Constanta, Romania, Tel.: +40241545015, \\ Email: trandafir.adina@yahoo.co.uk,octav.negurita@spiruharet.ro, \\ claudia.borsan@spiruharet.ro
}

\begin{abstract}
How to cite: TRANDAFIR, A., NEGURIȚĂ, O., GUNI, C. (2018). "The Impact of Deflation on Fiscal Aggregation." Annals of Spiru Haret University. Economic Series, 18(3), 81-95, doi: https://doi.org/10.26458/1836

Abstract

This article addresses the phenomenon of deflation from a historical perspective, a phenomenon rarely encountered in our days. Deflation is generally defined as the fall in the aggregate level of the consumer price index, respectively, the reverse inflationary phenomenon. The article also presents, in addition to experiences in different countries in times when deflation has been more pronounced and longer, and the effects it may have on public finance aggregates. The paper analyses the literature of all time that deals with the subject, as well as a presentation of the empirical data recorded, and an econometric analysis wishing to highlight the impact that the aggregate index of prices may have on public debt, using data recorded in Romania during 2000-2017.
\end{abstract}

Keywords: deflation; consumer price index; fiscal aggregates.

JEL Classification: $\mathrm{E}_{60}$

\section{Introduction}

The behaviour of aggregate price movements has often been at the centre of policy decisions and economic research. Research over the last decades has been largely focused on inflation, not deflation, for obvious reasons. 


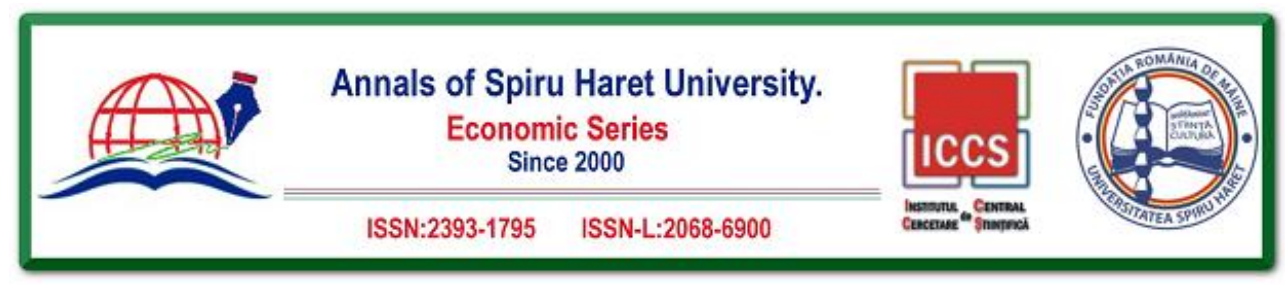

Issue $3 / 2018$

Some countries have had relatively recent deflationary experiences, especially Japan, which has real concerns about this. In Japan, the apparently rooted nature of deflation and its association with slow economic activity generated parallel to the Great Recession. At the same time, deflation - defined here only as a decrease in the aggregate level of prices of goods and services currently produced - has so far been largely limited to parts of Asia.

Deflation is defined as a sustained decrease of aggregate measure of prices, such as the consumer price index or the GDP deflator [IMF, 2003].

One or two quarters of price declines would not be worrying; it could not be deflagration from a technical point of view. However, even a slight but continuous deflation could be a cause for concern as it could increase economic uncertainties, distort resource allocation, have distributional consequences, and lead to growth performance below expected levels. This definition excludes that deflation may also represent changes in relative prices. In any economy, there will always be sectors where prices fall in relative or even absolute terms. This reflects the normal functioning of the market mechanism, whereby changes in sectoral prices play a central role in the allocation of resources.

The fear of deflation is generally based on the belief that it is associated with the recession [Stern, 2003], reflecting developments in the 1930s when the combination of deflation and economic contraction triggered the deflation of debt.

\section{Deflation Experiences}

Deflation is a rarely encountered phenomenon nowadays.

Before the onset of deflation in Japan since the mid-1990s, there were few episodes of sustained deflation, long the post-war period of the Second World War in major economies. Developed countries such as Canada, Norway and Sweden experienced small and short-lasting decreases in consumer prices in the late 1980s, and private consumption deflator decreased in Germany in 1986 (mainly due to a supply shock) and in Japan in 1988. Several Scandinavian countries have experienced a decline in asset prices, a sharp drop in production and a severe banking sector crisis in the late 1980s and early 1990s. However, these phenomena were generally not accompanied by a fall in aggregate prices. A number of emerging markets and developing countries have also experienced declines in prices by the mid-1990s. But declines were generally short-lived, reflecting natural disasters or severe declines in trade, exports of goods (CFA countries have experienced similar price shocks: Benin, Burkina Faso, Côte d'Ivoire, Guinea-Bissau, Mali, Niger, 


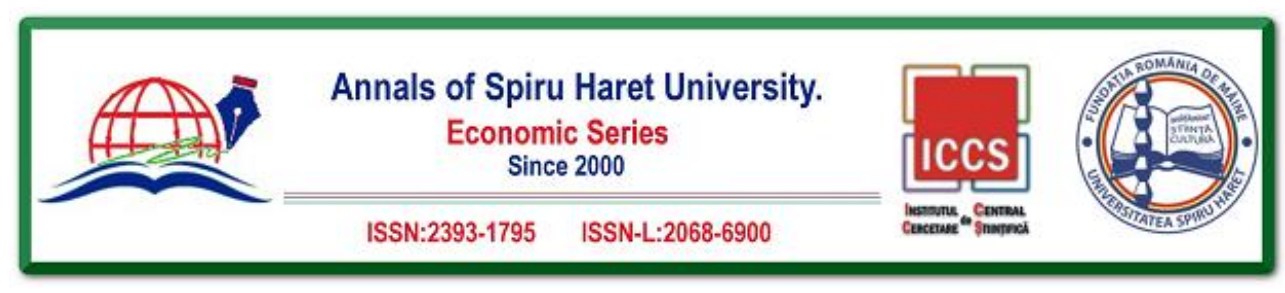

Issue 3/2018

Senegal, Togo). However, as mentioned above, the frequency of falling prices in both industrial and emerging countries has clearly increased over time.

In order to assess the periods of marked and sustained price declines, it is therefore necessary to take into account the pre-World War II period. In the following, two periods will be presented: industrial countries' experience in the last quarter of the $19^{\text {th }}$ century, when mild, but persistent deflation in the first half of the period was followed by inflation in the second half of the year; and secondly, the experience of the United States, Japan and Sweden in the 1930s, when severe deflation lasted for a shorter period, but was accompanied by very serious consequences. Recent experience in Japan has shown that mild deflation has been accompanied by stagnation in production, and China's very different experience has shown us that less persistent deflation has been accompanied by increased production.

An analysis of historical episodes lead to three main conclusions: first, deflation and deflationary expectations can occur surprisingly fast; second, deflation can impose serious economic costs, unless it mainly reflects positive supply shocks; and thirdly, determined and vigorous policies can make a crucial difference in effective and relatively rapid deflation [Bayoumi \& Collyns, 1999].

\section{The Deflation Experience of the Nineteenth Century}

From a broader historical perspective, secular increases in the aggregate price level are a phenomenon that characterizes the second half of the twentieth century.

For much of the recorded history, prices have risen due to supply shocks, including military conflicts or agricultural losses, but by ignoring these factors, prices have been as large as declines: there have been few episodes of sustained inflation. Throughout the $19^{\text {th }}$ century, there has been a sharp fall in the aggregate consumer price index in several major economies. In the United States, the index, in 1900, was about half of its value since 1800; in the United Kingdom, it was onethird smaller. Taking into account an even longer period, the aggregate price level in the United Kingdom and the United States was virtually the same in 1900 as in 1700 .

Prices dropped largely due to the constraints imposed by the gold standard in an environment where there was a significant excessive demand for gold. The increase in demand for money was driven by technological change and population growth. At the same time, the supply of gold was largely fixed. The constraints imposed by the limited gold offer partly manifested in deflationary episodes and relatively weak growth: despite the extraordinary technological revolution, annual real GDP growth 


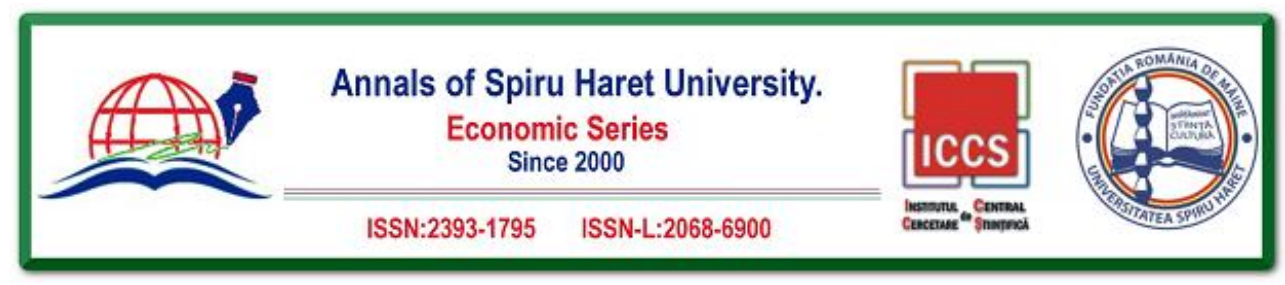

Issue 3/2018

per capita was over $1 \frac{1}{2}$ percent annually throughout the century; in U.K. was just under $1 \%$.

Although there are several opinions on the exact effects of deflation, especially in the last quarter of the $19^{\text {th }}$ century, there is a broad consensus on the following issues:

- Deflation periods were generally associated with significant social and political disruption; there have been increases in debt and bankruptcy;

- There was a significant volatility in output growth, with deflationary periods being marked by frequent financial crises;

- Inflation periods, such as the last decade of the nineteenth century, were generally higher than the deflation periods sustained in the 1870 s and early 1880 s [Lindert \& Williamson, 1985; Frieden, 1993; Bordo \& Redish, 2003].

However, GDP growth was positive over the period of deflation. There are two main explanations for this:

1. Firstly, downward periods have occurred in times of relatively favourable supply shocks. These included major episodes of disseminating new technologies, including the spread of railways and electrification.

2. Secondly, prices have not fallen too much to drive the expectations of a deflationary spiral becoming rooted. This assumption is supported by the long-term interest rate behaviour that has not fallen during deflationary episodes. In addition, financial intermediation played a less important role in the nineteenth century, and nominal rigidities were probably less rooted than at present [Bordo et al., 2000].

\section{Deflation in the Twentieth Century}

Deflation in the late 1920 s and early 1930 s was qualitatively and quantitatively different from the nineteenth century. In the United States, the consumer price index (and GDP deflator) declined by 24 percent between August 1929 and March 1933, after it was virtually constant from 1921 to 1929 . This decline was accompanied by a decline in real GDP of almost 30\%. Similar price declines took place in other countries; from 1929 to 1933, prices fell by $25 \%$ in Japan and by $20 \%$ in Sweden.

Unlike the nineteenth century, a collapse of aggregate demand and credit channels, along with political mistakes, led to deflation from the late 1920s and early 1930s. There is a broad consensus that monetary factors have played a crucial role both in the onset and prolongation of deflation and in the Great Recession. Ohanian (2017) shows that the initial decline in August 1929 and the length and severity of 


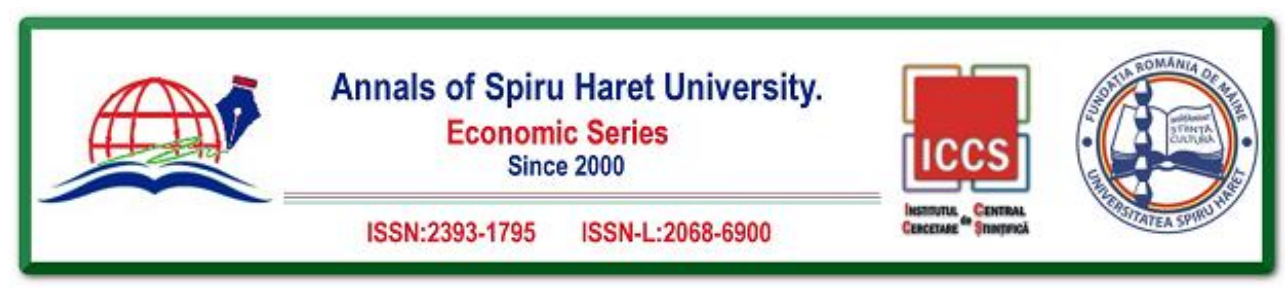

Issue 3/2018

the Great Depression were due to a restrictive monetary policy that led to a drastic decline in money supply. Bernanke (1995) highlighted the disruption of banking intermediation and Eichengreen (1995) showed the impact of international financial activities. These factors are now generally considered to be more important than the stock market collapse, for example, for the role they played in the Great Depression. In addition to the two above factors, the uneven distribution of income and wealth has also been seen as an important factor.

Arellano and Bai (2017) emphasize that there is a broad consensus that the recession was caused by an exogenous global contraction, mainly driven by the United States and transmitted abroad through a combination of political errors and technical deficiencies in the interwar golden standard. This conclusion is also supported by the clear divergence of economic performance between countries that have abandoned the gold standard at the beginning of the recession and those who have kept it.

In the United States, regarding the Federal Reserve two political mistakes have been made. First, the initial collapse of prices and demand was considered "necessary" to correct the excess of the 1920s [Guimaraes, Machado and Ribeiro, 2016]. The collapse was seen as a result of non-monetary forces - including the creation of surplus capacity in the late 1920s - and beyond the influence of monetary policy. The high number of bank failures since the 1930s was the result of poor management and lending for speculative shares and land transactions. Secondly, it tried to maintain the gold standard. While the Federal Reserve fell, he did not pay attention to the money supply. The discount rate dropped from $6 \%$ at the beginning of 1930 to $0.5 \%$ in the first part of 1931 . The update rate was temporarily high in response to the British abandonment of the gold standard in September 1931. However, bank lending has stopped practically, and with the high deflation rate, real interest rates have risen sharply. The golden standard was maintained until 1933.

Sweden and, to a certain extent, Japan offers examples of decision-makers who have been able to prevent deflationary forces through strong actions. Sweden experienced a similar deflation, albeit slightly more pronounced, than that of the United States in the late 1920s. Consumer prices have gradually diminished, and wholesale prices have risen sharply since the end of 1928, because the golden standard has sent deflationary pressure to Sweden. Industrial output declined by $21 \%$ in 1929-1931, compared with a 46\% drop in the United States. At the end of 1931, Sweden left the gold standard, the Swedish central bank explicitly adopted a price 


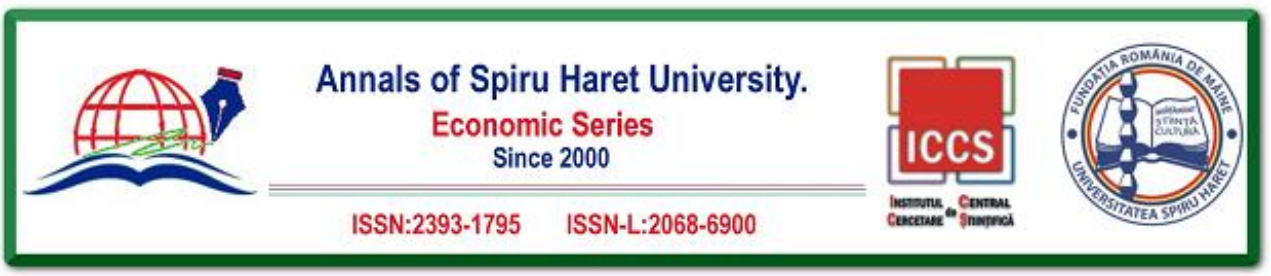

\section{Issue 3/2018}

target and implemented a policy that included open market operations to achieve this goal. Abandoning the gold standard has been a huge increase in confidence and a signal that the government has not been prepared to allow continued deflation. This has been underpinned by the price level targeting framework that underlines the government's decision to end disaggregation.

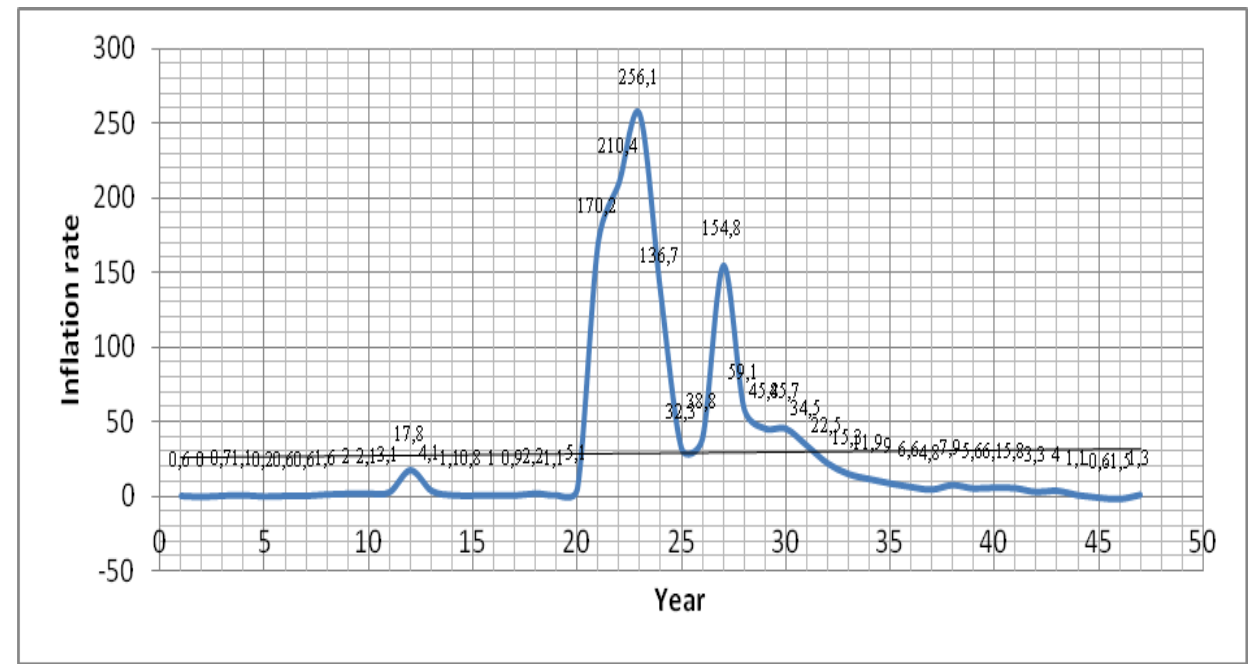

Fig. 1. Evolution of Inflation Rate in Romania, 1971-2017

Source: http://www.insse.ro/cms/ro/content/ipc-serii-de-date

Japan also managed to stop deflation by adopting strong measures. It temporarily returned to the gold standard in 1929, but between 1930 and 1931 there was a sharp decline in Japanese exports, which led to a fall in production and rapid deflation. Wholesale prices dropped by about $30 \%$ in 1930-1931. The gold standard was abandoned in December 1931, followed by a depreciation of the exchange rate, a marked relaxation of monetary policy and large-scale public spending. The Bank of Japan has subscribed a substantial portion of the government bond issue. These measures led to a sudden return of Japanese domestic demand and the end of deflation; wholesale prices increased substantially over the 1932-1933 period. However, in the absence of a clear price-steering commitment to Sweden, and the 


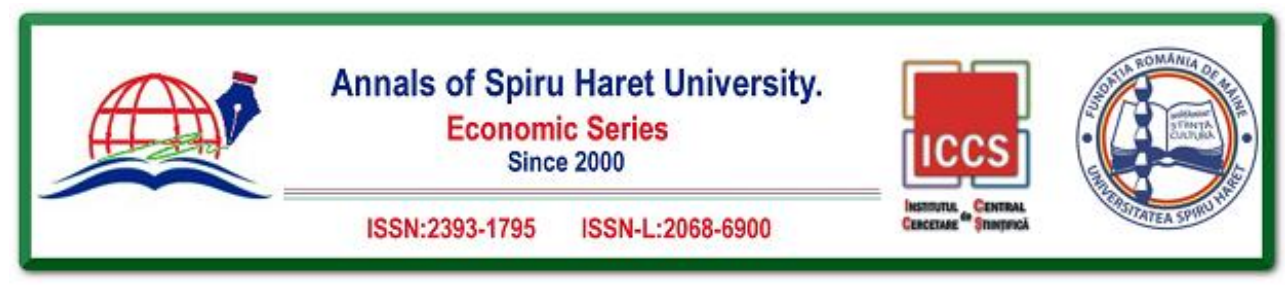

Issue 3/2018

rapid rise in government spending and the monetization of war-induced deficits, inflation accelerated considerably in the second half of the 1930s.

\section{The Romanian Experience}

Although Romania does not necessarily have a deflation experience, in this subchapter it will be presented the evolution of the rate of inflation in our country during 1971-2017. There have been periods (see Figure 1) in the 47 years analysed, where the inflation rate in our country was very low or even zero (1971-1981, 19841989, and 2012-2014).

A short deflationary episode, as this phenomenon understood as a fall in consumer prices, was between $2015(-0.6 \%)$ and $2016(-1.5 \%)$ as a result of the reduction, in the summer of 2015 , of VAT on food, which led to a $7 \%$ fall in consumer prices.

In Romania we can speak of an experience of inflation, especially since 1989, when they recorded highs inflation rate $(170.2 \%$ in $1991,210.4 \%$ in $1992,256.1 \%$ in $1993136.7 \%$ in 1994 and $154.8 \%$ in 1997).

\section{The Deflation Impact}

Public finance is vulnerable to deflation. The effect of deflation on debt rates has been described since the 1930s by Fisher (1933). In addition, deflation can affect primary balances through its impact on revenue and expenditure.

\section{The Impact of Deflation on the Public Budget}

During deflationary periods, the primary balance is affected by the magnitude and speed of revenue and expenditure adjustment.

I. Effects of Deflation on Public Revenues

The net impact of deflation on public revenues is affected by a variety of factors. An immediate impact is the loss of seigniorage revenue, which is the real revenue that governments gain through the use of new money to buy non-monetary and monetary assets.

Under a monetary system without any monetary policy action, seigniorage income is equivalent to a tax on inflation, given by the product of the inflation rate and the real monetary balance. In principle, deflation reduces seigniorage for a certain level of the real monetary balance - thus generating a deflation subsidy. However, if deflation leads to an increase in holdings in real money balances, the actual tax base will increase, which will lead to a possible increase in seigniorage 


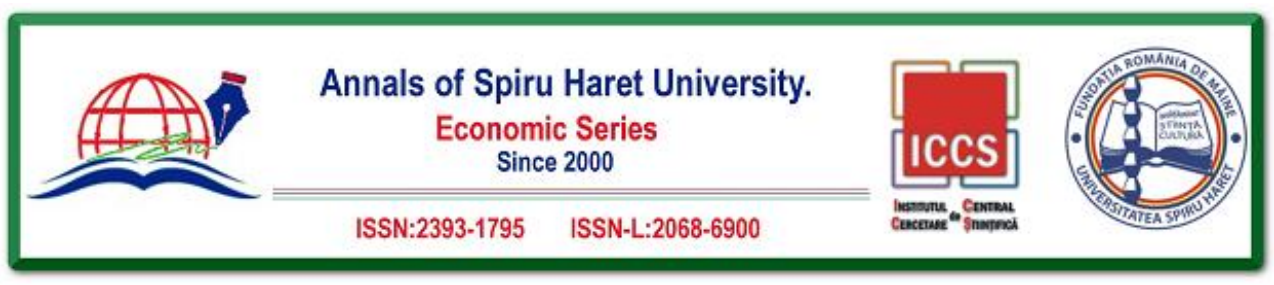

Issue 3/2018

revenues. Some studies suggest that potential seigniorage earnings are limited in today's advanced economies, because monetary aggregate (M1) is relatively lower than GDP. Simulations made by Akitoby et al. (2014) for G7 countries indicates that an additional inflation point would account for about $0.12 \%$ of annual GDP for additional seigniorage. This effect is considered to have been much higher in the past, before financial innovations, when there was no such difference between broad money and money in circulation or base money.

Under a completely proportional tax system, deflation would have no impact on the ratio between revenue and GDP: each component of GDP would be similarly taxed and both nominal revenues and GDP would react in similar proportions, leaving the report unchanged. However, the composition of the price shock counts because tax bases may differ in both nominal and real terms. For example, an oil price shock will have a greater effect on private consumption prices than on GDP deflators. However, in real life, because tax systems always include distorting features, there are reasons to believe that revenue rates will be affected by deflation.

Certain factors tend to reduce revenue weights in GDP during deflation periods. Firstly, the progressive nature of the tax system counts. In a progressive system, when tax thresholds are not perfectly indexed to inflation, deflation will tend to reduce revenue ratios by moving certain taxpayers to smaller tax cuts / limits, which will lead to lower revenue collection; and vice versa, in a regressive system. Second, the weights of GDP revenue will tend to suffer due to deflation if tax exemptions are widespread. Such exemptions are often set in nominal terms, and related costs increase when prices fall.

Other factors tend to increase the share of revenue in GDP during deflationary periods. First, some revenue components, such as excise duties and non-tax revenues, are by nature more inelastic than price and income taxes. Their inertia in deflation tends to increase revenue as a percentage of GDP (for example, transfers or interest payments received are often predetermined). Secondly, deflation can have effects on tax bases through behavioural effects. During deflation, consumption tends to move towards bigger goods, partly because prices are adjusting faster than revenue. Because these goods tend to be more taxed, and this will help the increase of revenues. It has been found, for example, that tax revenues in the early 1930s remained relatively high in several European countries, as consumption was more resilient, while investment fell sharply. For example, the case of France described in Sauvy (1965). Similarly, if consumer prices fall faster than GDP deflator, then the 


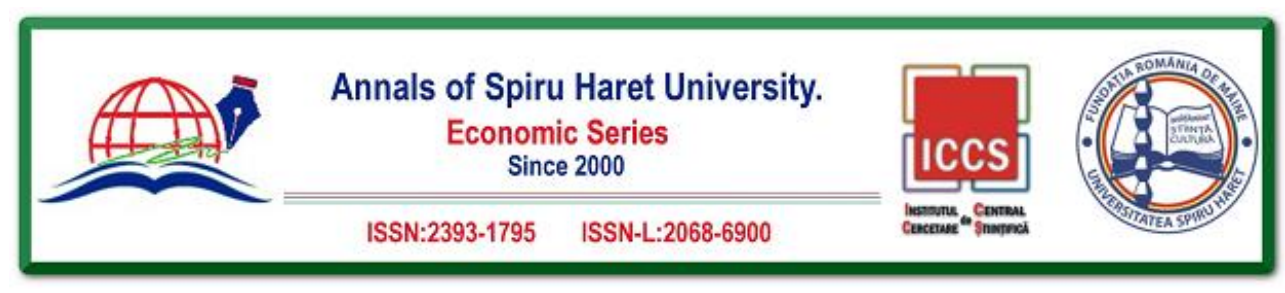

Issue 3/2018

revenue share will increase. Finally, the central bank's actions against prolonged deflationary pressures, in the form of quantitative easing policies, can generate income from seigniorage.

The above effects could be mitigated if the tax thresholds were indexed. Under a full indexing mechanism, during the deflation period, provisions are automatically adjusted to lower levels - including minimum income tax - in order to maintain constant the fiscal pressure. Policy makers may prevent indexation from falling during deflation periods. From a political point of view, it is difficult to raise nominal taxes, given the traditional currency illusion that prevails in such circumstances [Fuhrer \& Tootell, 2003]. Even with indexing, any waiting error tends to be positively correlated with tax revenue. The net effect of these indexing mechanisms will be similar to that described in a non-distortion system, income-GDP ratios immune to deflation.

\section{Effects of deflation on public expenditures}

Generally, public spending tends to be more sensitive to deflation than revenue collection because of nominal rigidity in the design of some of its components. It can be politically difficult to reduce wages and social transfers when prices fall. As a result, during deflationary periods, the freezing of nominal expenditure may be the only feasible option, which leads to an increase in the share of expenditure in GDP [Aguiar and Amador, 2016]. This is particularly true for social insurance (pensions and other benefits) and wages. Although public wages are generally indexed to official inflation expectations, there is likely to be a downward rigidity due to political economy considerations. In Japan, for example, indexation mechanisms, which otherwise would have triggered nominal discounts for some social spending, were suspended for several years during the deflationary period.

Contractual arrangements, such as multiannual agreements and price index provisions, may also delay the transmission of deflation to capital expenditure [Huang, Meng and Xue, 2017; Dupor and Guerrero, 2017]. Price indexation mechanisms are generally provided only in long-term contracts such as leasing contracts. This feature may also apply to certain recurring expenses if specified in multiannual contracts (maintenance, outsourcing, etc.). In these cases, price adjustments will be limited to new and renewed contracts and will take some time to be fully reflected in tax aggregates.

Finally, designing budgets or fiscal rules might delay response to an unexpected shock of deflation. Since budgets are usually prepared and executed in nominal 


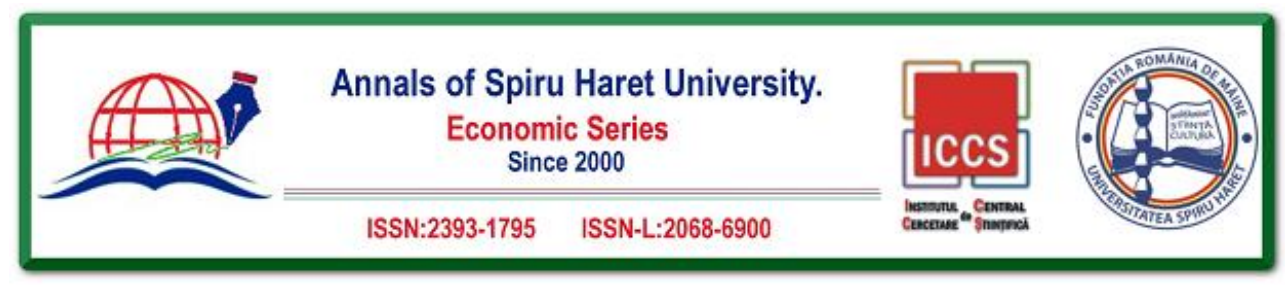

Issue 3/2018

terms, it may be difficult to adjust the lines of expenditure to unexpected deviations from budget forecasts in a given fiscal year.

\section{The Impact of Deflation on Public Debt}

Deflation has a negative impact on debt ratios, if not fully anticipated in the nominal interest rates. This effect works through the initial stock of debt and the combined effect of the real interest rate and the primary balance [Hsing, 2017]. First, for any stored debt and real growth rates, deflation mechanically increases the debt-to-GDP ratio: it reduces nominal GDP, pushing the ratio upwards. Secondly, the primary balance may unexpectedly deteriorate in a deflationary environment, which would lead to a further increase in debt [Nicolas End et al., 2015]. Third, for any given nominal interest rate and for real growth rates, deflation raises the real value of the interest rate. If the interest rate is not flexible or deflation is not anticipated, the nominal rates do not adjust immediately to absorb the shock. Under Fisher's law, interest rates would remain constant in real terms.

In general, interest payments are largely based on contractual interest rates, which are largely fixed and do not adapt to short-term domestic prices. The impact of this channel depends on the maturity structure and monetary denomination of sovereign debt, as well as the share of indexed bonds in the total debt ratio [according to Akitoby et al., 2014].

These mechanisms can be summed up in the dynamic debt equation, which correlates the year-to-year evolution of the debt to GDP ratio on the existing debt stock, by the impact of nominal interest rates, inflation and output growth on the primary balance, and any stock-flow adjustments.

In order to highlight the impact of the deflation, or more correctly, of the consumer price index on public debt, the effect that the aggregate price index has on the total public debt in Romania in 2000-2017 will be analysed below. I would like to point out how this indicator can influence the public debt, because in Romania, during this period, one cannot speak of an accentuated deflationary phenomenon even with the short experience of 2015-2016.

In order to highlight the impact of consumer price index on the public debt, we used an econometric study with a linear regression equation of the form:

$$
\mathrm{Y}=\alpha+\beta^{*} \mathrm{X}
$$

where: $\mathrm{Y}$ is the dependent variable; $\mathrm{X}$ is an independent variable; $\alpha, \beta$ are the regression equation parameters. 


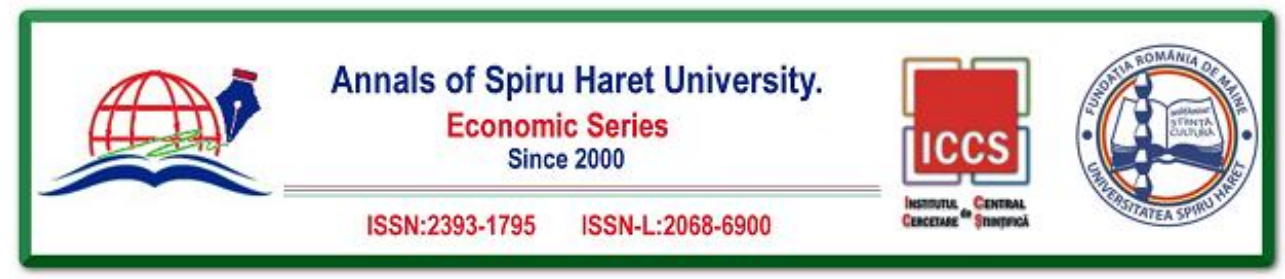

Issue 3/2018

In this case, we considered the total public debt as dependent variables, and as an independent variable, the consumer price index in 2000-2017. This equation has to show the influence of consumer price index on public debt in Romania.

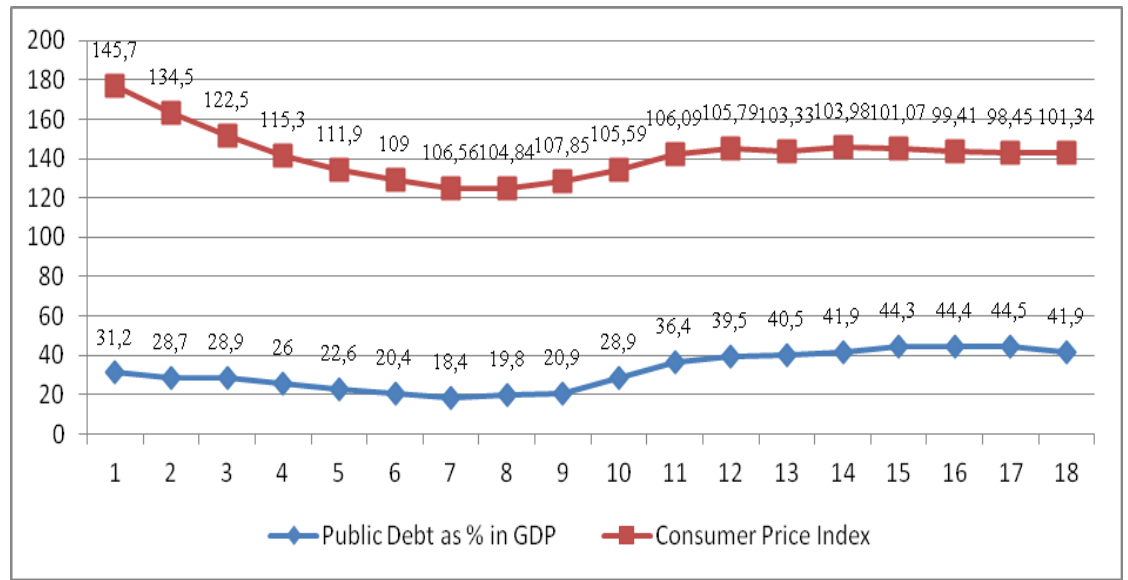

Fig. 2. Evolution of Total Public Debt (PD) as Share of GDP and Consumer Price Index in Romania (PI) (2000-2017)

Source: Own processing of data available on: http://www.insse.ro

Romania's public debt, as it can be seen in the figure above, has exceeded $40 \%$ of GDP since 2012. The maximum was reached in 2014 (44.3\%), 2015 (44.4\%) and $2016(44.5 \%)$. For 2017, public debt is $41.9 \%$ of GDP. The aggregate price index decreased during the $2000-2007$ period, from $145.7 \%$ to $104.84 \%$ and then fluctuated.

The equation considered is:

$$
\mathrm{PD}=\alpha+\beta^{*} \mathrm{PI},
$$

where: PD is the total public debt, the dependent variable; PI is the price index, the independent variable; $\alpha, \beta$ are the regression equation parameters.

Following econometric calculations, the following results were obtained: 


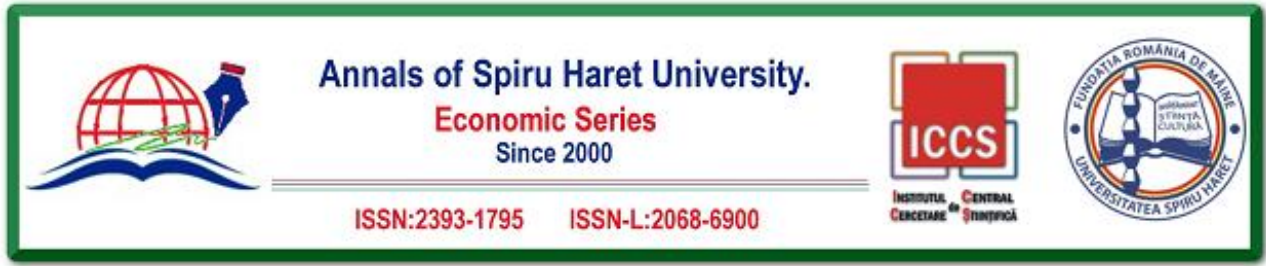

Issue 3/2018

Table 1. The Regression Equation between Public Debt (PD) and Price Index (PI)

\begin{tabular}{|c|c|c|c|c|}
\hline \multicolumn{5}{|c|}{ Dependent Variable: PD } \\
\hline \multicolumn{5}{|c|}{ Method: Least Squares } \\
\hline \multicolumn{5}{|l|}{ Sample: 20002017} \\
\hline \multicolumn{5}{|c|}{ Included observations: 18} \\
\hline \multicolumn{5}{|c|}{$\mathrm{PD}=\mathrm{C}(1)+\mathrm{C}(2) * \mathrm{PI}$} \\
\hline & Coefficient & Std. Error & $\mathrm{t}$-Statistic & Prob. \\
\hline $\mathrm{C}(1)$ & 60.38721 & 20.02301 & 3.015890 & 0.0082 \\
\hline $\mathrm{C}(2)$ & -0.256036 & 0.180646 & -1.417335 & 0.1756 \\
\hline R-squared & 0.111547 & \multicolumn{2}{|c|}{ Mean dependent var } & 32.17778 \\
\hline Adjusted R-squared & 0.056019 & \multicolumn{2}{|c|}{ S.D. dependent var } & 9.552613 \\
\hline S.E. of regression & 9.281193 & \multicolumn{2}{|c|}{ Akaike info criterion } & 7.398296 \\
\hline Sum squared resid & 1378.249 & \multicolumn{2}{|c|}{ Schwarz criterion } & 7.497227 \\
\hline Log likelihood & -64.58467 & \multicolumn{2}{|c|}{ Durbin-Watson stat } & 0.166216 \\
\hline
\end{tabular}

Source: Own processing of data available www.insse.ro

Using the least squares method in EViews, the following regression equation was obtained:

$$
\mathrm{PD}=60.38-0.256^{*} \mathrm{PI}
$$

According to this equation to a change in price index by $1 \%$, public debt will change in the opposite direction with 0.256 percent as a share of GDP. The coefficient of determination for regression (R-squared) signifies the fact that $11.15 \%$ of the variation in the public debt is explained by the modification of the price index.

For a better accuracy of this study and to show the influence of deflation on public debt, a separation between the value of the public debt annuity and the value of the interest rate is required. This is due to the fact that the price index influences this latter indicator.

\section{Conclusions}

This article aims to address the issue of the impact of deflation on tax aggregates. The article also addresses deflation from a historical perspective, showing the periods in which it has been more pronounced and longer, as well as analysing the literature of all times that addresses this issue.

92 


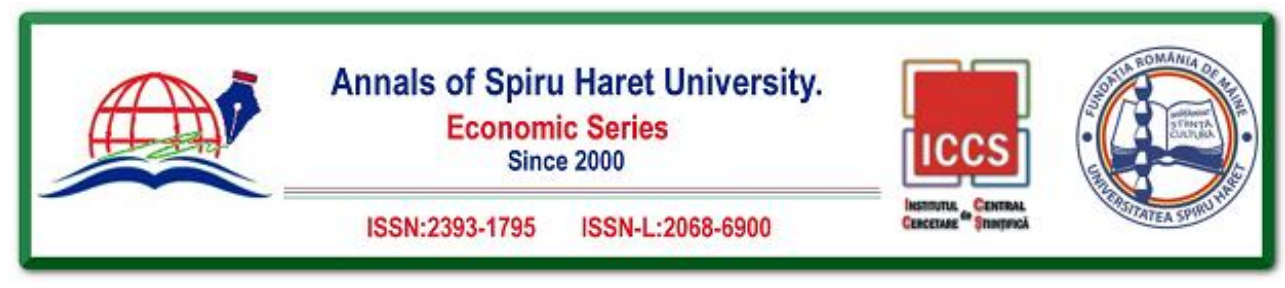

Issue 3/2018

The conclusions drawn from this study can be synthesized as follows:

First, the effects of deflation are probably nonlinear in the sense that they should be more than proportional to their intensity. In particular, they depend on certain constraints that become mandatory, such as the nominal inflexibility of wage declines and the zero boundaries related to the lower limit. Instead, the extent to which they become mandatory will depend on factors such as increasing the underlying economy and, in general, by its strength and flexibility.

Secondly, apart from the reverse causality, part of the weakness of the economic activity observed in deflationary periods can obviously appear from deflation, but if the deflation rate remains low, many problems can result from developments for which, in the best case, deflation only plays a role of symptom. For example, taking into account historical fluctuation intervals, asset price reductions may obviously have a significantly greater effect on balance sheets and hence on funding constraints and / or the desire to spend than deflation itself, more chosen if accompanied by an extended banking crisis [Borio \& Lowe, 2002, Bordo \& Jeanne, 2002]. As noted in other speciality papers, it is difficult to see how the low deflation from Japan in the early 2000s could be the main reason for stagnating production, at least compared to the major asset price depression [Okina \& Shiratsuka, 2003, Koo, 2003, Ahearne et al., 2002].

Third, there is, in fact, no reason to expect deflation to be necessarily associated with economic weakness. This is why researchers have sometimes categorized deflation in different types, depending on the context in which it occurs [Bordo et al., 2002; Greer and Denison, 2017]. "Good" deflation would reflect productivity improvements against backdrop of underlying falls in nominal demand growth. These could be coupled with higher growth, high asset prices and a healthy expansion of money and credit aggregates, reflecting that lower prices will not affect profitability and cash flows. Good deflation could also be the transient and mild declines in the aggregate price level of normal cyclical crises in a low-inflation environment. The costs of such episodes cannot be clearly distinguished from those of similar positive inflation deviations from the objectives of "price stability". "Bad" deflation would be that in which specific nominal rigidities played an important role in undermining economic activity, or if other concomitant developments led to severe economic weakness.

Extending such terminology, "ugly" deflation could be considered as the one in which deflationary forces have conspired with the asymmetries of creating a spiral, in a context in which the self-balancing mechanisms of the economy have failed to 


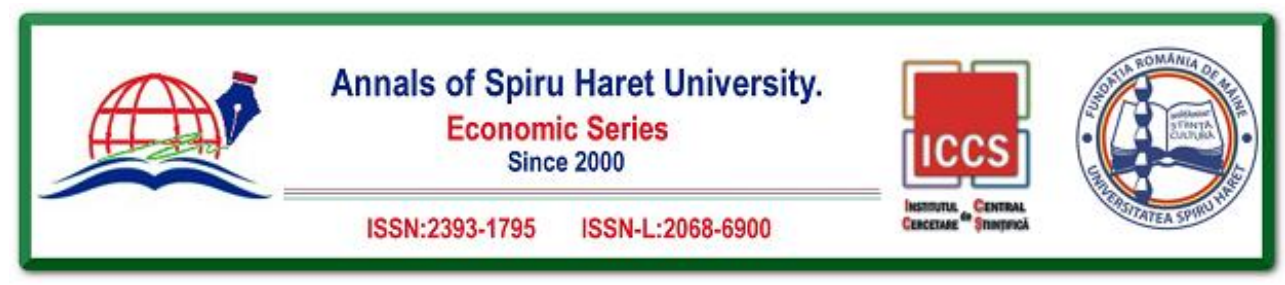

Issue 3/2018

function satisfactorily. The great depression of the interwar years could be considered as a case in this respect.

\section{References}

1. Aguiar, M., Amador, M. (2016). "Fiscal Policy in Debt Constrained Economies." Journal of Economic Theory, 161, pp. 37-75.

2. Ahearne, A., Gagnon, J., Haltimaier, J., Kamin, S. et al. (2002). "Preventing Deflation: Lessons from Japan's Experience in the 1990s." Federal Reserve Board International Finance Discussion Papers, no 729, June.

3. Akitoby, B., Komatsuzaki, T., \& Binder, A. (2014). "Inflation and Public Debt Reversals in the G7 Countries." IMF Working Paper No. 14/96, available at: https://www.imf.org/external/pubs/ft/wp /2014/wp1496.pdf, accessed March, 6th.

4. Arellano, C., Bai, Y. (2017). "Fiscal austerity during debt crises." Economic Theory, 64(4), pp. 657-673.

5. Bayoumi, Tamim, \& Collyns, Charles. Post-buble Blues: How Japan Responded to Asset Price Collapse, IMF: Washington, DC, 1999.

6. Bernanke, Ben (1995). "The Macroeconomics of the Great Depression: A Comparative Approach." Journal of Money, Credit, and Banking (February), pp. 1-28.

7. Bordo, M., \& Eichengreen, B. (2002). "Crises Now and Then: What Lessons from the Last Era of Financial Globalisation?" NBER Working Paper, no 8716, January.

8. Bordo, M., \& Jeanne, O. (2002). "Boom-busts in Asset Prices, Economic Instability, and Monetary Policy." NBER Working Paper, no 8966, June.

9. Bordo, Michael D., \& Redish, Angela (2003). "Is Deflation Depressing? Evidence from the Classical Gold Standard." NBER Working Paper 9520.

10. Bordo, Michael, Erceg, Christopher, \& Evans, Charles (2000). "Money, Sticky Wages, and the Great Depression." American Economic Review, Vol. 90, No. 5, pp. 1447-1463.

11. Borio, C., \& Lowe, P. (2002). "Asset Prices, Financial and Monetary Stability: Exploring the Nexus, Paper Presented at the BIS Conference on 'Changes in Risk Through Time: Measurement and Policy Options", BIS Working Papers, no 114, Basel, July.

12. Dupor, B., Guerrero, R. (2017). "Local and aggregate fiscal policy multipliers." Journal of Monetary Economics, 92, pp. 16-30.

13. Eichengreen, Barry. Golden Fetters: The Gold Standard and the Great Depression, Oxford University Press, 1995, pp. 119-139.

14. Farhi, E., Werning, I. (2017). "Fiscal unions." American Economic Review, 107(12), pp. 3788-3834.

15. Fisher, Irving (1933), "Debt Deflation Theory of Great Depressions." Econometrica, Vol. 1, pp. 377-57. 


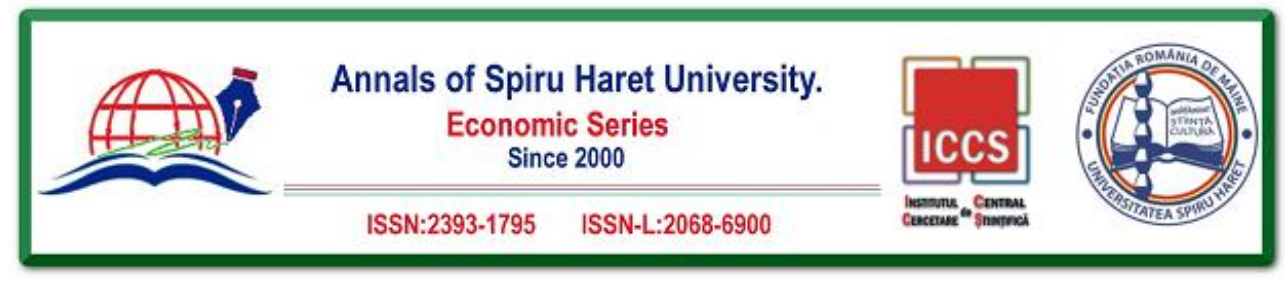

Issue 3/2018

16. FMI (2003). "Deflation: Determinants, Risks, and Policy Options — Findings of an Interdepartmental Task Force", available at http://www.imf.org/external/pubs/ft/def/ 2003/eng/043003.htm, accessed March, $10^{\text {th }}$.

17. Frieden, Jeffrey. "The Dynamics of International Monetary Systems: International and Domestic Factors in the Rise, Reign, and Demise of the Classical Gold Standard." In Jack Snyder \& Robert Jervis (eds.), Coping with Complexity in the International System, Boulder: Westview Press, 1993.

18. Fuhrer, J., \& Tootell, G. (2003). "Issues in Economics: What Is the Cost of Deflation?" Regional Review, Q3, pp. 2-5.

19. Greer, R. A., Denison, D. V. (2016). "Determinants of Debt Concentration at the State Level." Public Budgeting and Finance, 36(4), pp. 111-130.

20. Guimaraes, B., Machado, C., Ribeiro, M. (2016). "A Model of the Confidence Channel of Fiscal Policy." Journal of Money, Credit and Banking, 48(7), pp. 1363-1395.

21. Hsing, Y. (2017). Is Real Depreciation or More Government Deficit Expansionary? The Case of Slovenia." South East European Journal of Economics and Business, 12(1), pp. 50-56.

22. Huang, K. X. D., Meng, Q., Xue, J. (2017). "Balanced-Budget Income Taxes and Aggregate Stability in a Small Open Economy." Journal of International Economics, 105, pp. 90-101.

23. Koo, R. Balance sheet recession: Japan's struggle with uncharted economics and its global implications, John Wiley and Sons, 2003.

24. Lindert, P., \& Williamson, J. G. (1985). "Growth, Equality and History." Explorations in Economic History, Vol. 22, No. 4 (October), pp. 341-377.

25. Nicolas End et al. (2015). "Deflation and Public Finances: Evidence from the Historical Records." IMF Working Paper WP/15/176, available at: https://www.imf.org/external/ pubs/ft/wp/201 5/wp15176.pdf, accessed March, $12^{\text {th }}$

26. Ohanian, L. E. (2017). "The Great Recession in the Shadow of the Great Depression. A Review Essay on Hall of Mirrors: The Great Depression, the Great Recession, and the Uses and Misuses of History," by Barry Eichengreen, Journal of Economic Literature, 55(4), pp. 1583-1601.

27. Okina, K., \& Shiratsuka, S. (2003). “Japan’s Experience with Asset Price Bubbles: Is It a Case for Inflation Targeting?” In W. Hunter, G. Kaufman, \& M, Pomerleano (eds), Asset Price Bubbles: The Implications for Monetary, Regulatory, and International Policies, MIT press, January, chapter 7, pp 81-99.

28. Sauvy, A. Histoire économique de la France entre les deux guerres, Paris: Fayard, 1965.

29. Stern, G. (2003). "Should We Accept the Conventional Wisdom about Deflation?" Federal Reserve Bank of Minneapolis, The Region (September).

30. www.insse.ro 
